\title{
Vascular pedicled iliac bone grafting is effective in patients with an early stage of femoral head avascular necrosis
}

\author{
Damar pediküllü iliyak greftleme erken evre femur başı avasküler nekrozlu hastalarda etkilidir
}

\author{
Nurzat Elmalı, M.D., ${ }^{1}$ Kadir Ertem, M.D., ${ }^{1}$ Mustafa Karakaplan, M.D., ${ }^{1}$ Demet Pepele, M.D., ${ }^{2}$ \\ Cihat Dağgez, M.D., ${ }^{1}$ Haldun Topgül, M.D. ${ }^{1}$
}

1'Department of Orthopedics and Traumatology, Medical Faculty of İnönü University, Turgut Özal Medical Center, Malatya, Turkey ${ }^{2}$ Department of Orthopedics and Traumatology, Adıyaman State Hospital, Adıyaman, Turkey

\begin{abstract}
Objectives: This study aims to evaluate clinical and radiological findings of a series of patients with avascular necrosis of the femur head (ANFH) treated by core decompression and vascular pedicled iliac crest grafting.

Patients and methods: This retrospective study included 26 hips of 22 patients (14 males, 8 females; mean age 36 years; range 16 to 48 years) with ANFH using the vascularized iliac bone grafting between March 2003 and July 2010 in our clinic. The main predisposing factor was steroid use in 13 patients. All patients were assessed clinically according to the Harris hip score and by radiographs by the Association Internationale de Recherche sur la Circulation Osseuse (ARCO) staging system.
\end{abstract}

Results: The mean follow-up was 36 (range 14 to 62) months. Eleven hips (42\%) had stage II and 15 hips (58\%) had stage III ANFH. The mean Harris scores increased from 52 (range 31 to 63 ) to 82.8 (range 62 to 90 ) after surgery. Based on clinical outcomes, 18 hips $(69 \%)$ were presented as excellent and good, while eight hips presented fair and poor. According to the ARCO staging system, satisfactory results were provided in $17(65 \%)$ of the 26 hips. Two of four hips at preoperatively stage II progressed to stage III, two other hips to stage IV. Five hips at stage III preoperatively progressed to stage IV and these hips had to undergo hip replacement.

Conclusion: Our results suggest that core decompression and the vascular pedicled iliac bone grafting are effective in early stages of ANFH.

Key words: Avascular necrosis; femoral head; vascularized iliac graft.
Amaç: Bu çalışmada femur başı avasküler nekrozu (FBAN) olan ve kor dekompresyon ve damar pediküllü iliyak kemik greftleme ile tedavi edilen hasta serisinin klinik ve radyolojik bulguları değerlendirildi.

Hastalar ve yöntemler: Mart 2003 ve Temmuz 2010 tarihleri arasında kliniğimizde vaskülerize iliyak kemik grefti uygulanan 22 FBAN hastasının (14 erkek, 8 kadın; ort. yaş 36 yıl; dağılım 16-48 yıl) 26 kalçası bu retrospektif çalışmaya alındı. Başlıca hazırlayıcı etken 13 hastada steroid kullanımı idi. Tüm hastalar klinik olarak Harris Kalça skoru ile ve radyolojik olarak ARCO (Association Internationale de Recherche sur la Circulation Osseuse) evreleme sistemi ile değerlendirildi.

Bulgular: Ortalama izlem süresi 36 (dağılım 14-62) ay idi. On bir kalça (\%42) evre II ve 15 kalça (\%58) evre III FBAN idi. Ortalama Harris kalça skoru ameliyat öncesi 52'den (dağılım; 31-63) ameliyat sonrası 82.8'e (dağılım; 62-90) yükseldi. Klinik sonuçlar 18 kalçada (\%69) iyi ve mükemmel iken, sekiz kalçada (\%31) yeterli ve kötü idi. ARCO evreleme sistemine göre, 26 kalçanın 17'sinde (\%65) tatminkar sonuç sağlandı. Ameliyat öncesi evre II olan dört kalçadan ikisi evre III'e, ikisi evre IV'e ilerledi. Ameliyat öncesi evre III olan beş kalça evre IV'e ilerledi ve bu hastalara total kalça artroplastisi uygulandi.

Sonuç: Çalışma bulgularımız, kor dekompresyon ve damar pediküllü iliyak kemik greft uygulamasının erken evre FBAN'nin tedavisinde etkili olduğunu göstermektedir.

Anahtar sözcükler: Avasküler nekroz; femur başı; damarlı iliyak greft

- Received: May 02, 2013 Accepted: November 21, 2013

- Correspondence: Nurzat Elmalı, M.D. İnönü Üniversitesi Tıp Fakültesi Turgut Özal Tıp Merkezi Ortopedi ve Travmatoloji Anabilim Dalı, 44280 Malatya, Turkey. Tel: +90422 - 3410660 / 5104 Fax: +90422 - 3410627 e-mail: nelmali@hotmail.com 
Avascular necrosis of the femoral head (ANFH) reflects the final common pathway of a range of insults to the blood supply and ultimately results in femoral head collapse in $75-85 \%$ of untreated patients..$^{[1-4]}$ Collapse leads to osteoarthritis and eventually requires total hip arthroplasty (THA). ${ }^{[5,6]}$ Total hip arthroplasty yields satisfactory results in the treatment of the end stage of ANFH in older patients. However, disease typically affects males between the ages of 20 and 40 years and joint replacement is not a suitable option for younger patients. Therefore, the current trend in the treatment of ANFH aims to preservation of the joint in the initial stages and to delay of replacement surgery in advanced cases. Several head preserving procedures such as core decompresion, osteotomies and non-vascularized or vascularized bone grafting have been used to avert the need for total hip replacement. ${ }^{[7-21]}$

The vascularized fibular grafting is associated with better clinical and radiographic results than non-vascularized fibular grafting in precollapse hips. ${ }^{[9-12]}$ The rationale of vascular pedicled fibula grafting procedure is based on the following points: decompression of the femoral head diminishes intraosseous pressure like compartment syndrome and improves the interrupted circulation which contributes the disease progression. Excision of the necrotic tissue which inhibits revascularization of the head and filling of the defect created after core with vascular pedicled bone graft is a viable method and supports the subchondral surface and enhances the revascularization process. However, the potential disadvantages of vascularized fibular grafting include prolonged surgery time, need of microvascular anastomosis technique, prolonged operative scar, associated donor site morbidity, and heterotopic ossification.

In this study, we aimed to test our hypotesis that core decompression and vascular pedicled iliac crest grafting reduces the intraosseous tension, thereby, achieving early revascularization and supports the subchondral bone of ischemic femoral head by an osteoinductive cancellous graft without the need for vessel anastomosis and with lower donor site morbidity. As a result, vascularized iliac bone grafting, in conjunction with core decompression, provides symptomatic relief and delay the need for THA in patients with Ficat stage II and III disease.

\section{PATIENTS AND METHODS}

Our institutional review board approved the study. Between March 2003 and July 2010 years, 26 hips of 22 patients (14 males, 8 females; mean age 36 years; range 16 to 48 years) with ANFH were treated with vascularized iliac crest transplant, perfused by the deep circumflex iliac artery. The left side was most frequently affected with 10 hips. Five patients were bilaterally affected. The main predisposing factor was steroid use in 13 patients. Of these, three patients had acute lymphoblastic leukemia (ALL), two patients with liver transplantation, two patients had idiopathic trombositopenic purpura (ITP), four patients with renal failure, and two patients had chronic obstructive lung disease. Of the other patients, two patients had alcohol use, two patients were pregnant. No predisposing factor was found in five cases.

All patients were assessed clinically during preand postoperative period according to the Harris hip score and radiologically by $\mathrm{X}$-rays and magnetic resonance imaging (MRI) to confirm the diagnosis and staging according to Association Internationale de Recherche sur la Circulation Osseuse (ARCO) classification system, a modified Ficat-Arlet staging system (Table I). ${ }^{[22,23]}$

The diagnostic criteria of avascular necrosis were based on pathognomonic radiographic changes (collapse of the femoral head, anterolateral sequestration, crescent sign), and a double-line on $\mathrm{T}_{2}$-weighted MRI. Radiologically, preoporative 11 hips (42\%) had stage II and 15 hips (58\%) had stage III avascular necrosis according to the ARCO classification system. The ARCO system was also used to classify the progression of hip disease postoperatively. Preoperative femoral angiography was performed to confirm the presence of deep circumflex iliac artery pedicle from all the patients. No control group was constituted. Informed consents were obtained from the patients.

\section{Surgical technique}

We used double incision technique which was first described by Eisenchenk et al. ${ }^{[12]}$ The patient was placed in supine position with the ilium on the side as the femoral head necrosis was lifted $15^{\circ}$. The skin incision similar to ilioingunial approach was made $2 \mathrm{~cm}$ proximal to the iliac crest (Figure 1). The aponeurosis of the obliquus transversus muscle was cut approximately $3 \mathrm{~cm}$ from the iliac crest up to the external inguinal ring. Lateral femoral cutaneous and ilioinguinal nerves were observed and preserved. The pedicle of deep circumflex iliac artery was palpable. The vessels were prepared and the respective vascular branches were ligated to the iliac vessels and iliac crest transplant. The mean size of the harvested grafts was $6 \times 2 \times 2 \mathrm{~cm}$. The vascularized transplant was kept extraperitoneally and the skin was closed temporarily. A second skin incision starting $8 \mathrm{~cm}$ proximal to the tip of the 
TABLE I

ARCO classification

\begin{tabular}{|c|c|}
\hline Stages & Radiologic changes \\
\hline Stage 0 & Negative/normal: XR/CT/MRI/scan \\
\hline Stage I & $\begin{array}{l}\text { Positive: MRI and/or bone scan. } \\
\text { Negative/normal: XR/CT }\end{array}$ \\
\hline Stage II & $\begin{array}{l}\text { XR: sclerotic, cystic or osteoporotic changes of } \\
\text { femoral head }\end{array}$ \\
\hline Stage III & $\mathrm{XR}$ : crescent sign \\
\hline Stage IV & XR: flattening of femoral head \\
\hline Stage V & $\begin{array}{l}\text { XR: flattening of femoral head, decreased joint } \\
\text { space and acetabular changes. }\end{array}$ \\
\hline Stage VI & Complete joint destruction \\
\hline
\end{tabular}

ARCO: Association internationale de recherche sur la circulation osseuse classification; XR: X-ray; CT: Computed tomography; MRI: Magnetic resonance imaging.

trochanter major to approximately $12 \mathrm{~cm}$ distally was made. The fascia lata was split and the gap between the gluteus medius muscle and tensor fasciae latae muscle was located. The gluteus medius muscle was reflected dorsally and proximally with a blunt instrument. After opening the joint capsule, a window approximately $6 \times 1.5 \mathrm{~cm}$ on the femoral neck was opened up to the trochanter major. This window should allow the emptying of the necrotic area and to placement of the graft (Figure 2). After necrotic material was excised with curette and high speed drill, temporary skin closure was opened (Figure 3). Sectioning of the tendon at the reflex portion of the rectus femoris, a sponge forceps instrument was pushed through the lacuna musculorum under the inguinal ligament. Before applying the pedicle graft to the necrotic area, small fragments of cancellous bone were introduced. The hip was flexed by placing a cushion under the knee to make pull-through of the vascularized transplant easier. The graft with pedicle removed from the iliac crest was inserted

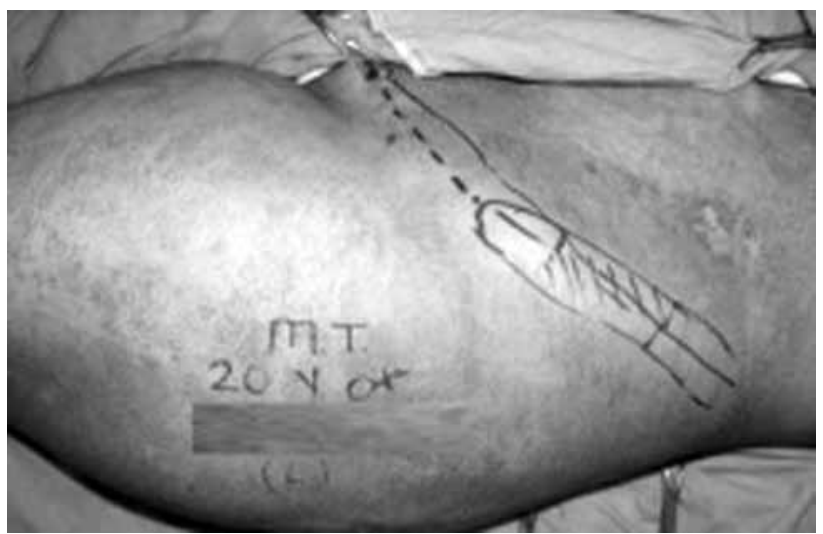

Figure 1. Intraoperative marking of skin incision for pedicled vascularized graft. to the area in the femoral head occupied by the necrotic bone. We positioned graft to femoral neck window without any fixation device by exerting some pressure. The wound was closed by layers. The mean duration of surgery time was 3.5 (range, 2.8-4.3) hours. The mean blood loss was 180 cc (120-200). No patient required postoperative transfusion and there were no wound infections. Two patients suffering from obesity with serious drainage were considered to having fatty necrosis. Drainage ceased at one week postoperatively. Selective digital subtraction angiography was performed in all cases to confirm the blood reconstruction of the femoral head.

In accordance with the postoperative protocol, the hip was positioned in $20^{\circ}$ flexion for three weeks to relax the pedicle postoperatively. Subsequently, walking was permitted without any weight bearing for six months.

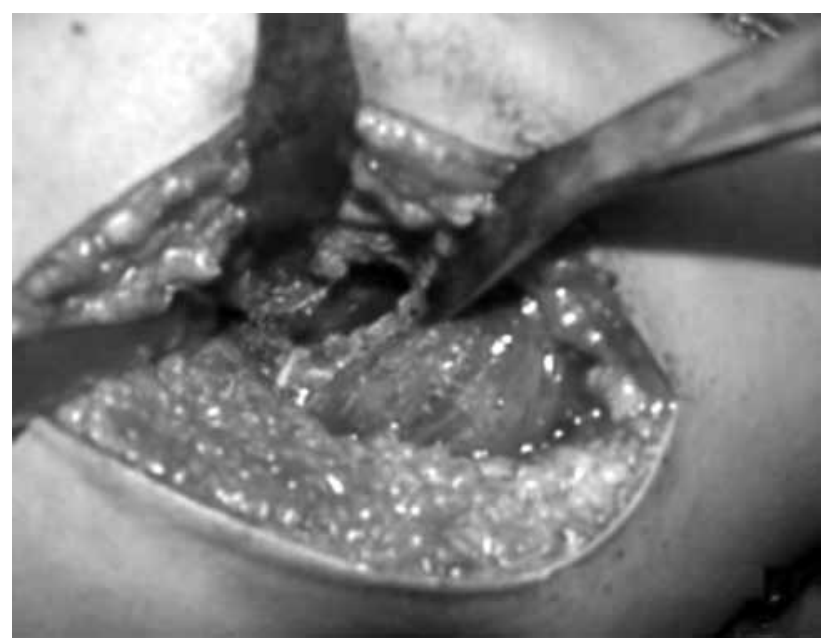

Figure 2. Window on the femoral neck to allow the emptying of the necrotic area and the placement of the graft.

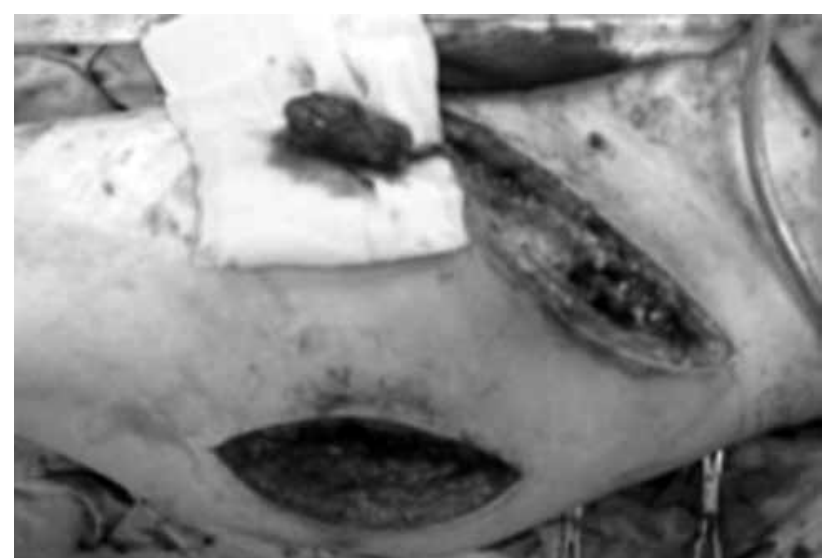

Figure 3. View after preparing vascularized graft and before placing to window on the femoral neck. 


\section{RESULTS}

The mean follow-up was 36 (range, 14-62) months. The clinical results were classified as excellent, good, fair and poor according to Harris hip score on which 91 point is excellent, $81-90$ is good, $71-80$ is fair, below 71 point is poor. Before operation, the mean Harris hip score was 52 points ( 48 to 72 ) and it was raised to 82.8 (72 to 90 ) points at three years during the follow-up. Eighteen hips (69\%) had good-excellent results; eight hips (31\%) had an excellent, and 10 hips (38\%) had a good result. Some patients had slight pain while walking or doing exercise, some had pain when they stood up from a sitting position. Eight hips (31\%) had fair and poor results; three hips (12\%) had fair result and five hips (19\%) had poor results. These patients walked with a limp and THA were performed five of them.

Radiologically, two hips at stage II progressed to stage III. Two hips at stage II progressed to stage IV and five hips at stage III progressed to stage IV. Unchanged radiological appearance over the follow-up period was observed in 17 hips (65\%) according to the ARCO classification after three years (Figure 4a-d).

The time from the initiation of corticosteroid therapy to the onset of osteonecrosis (as assessed by MRI) ranged from one to 16 months, with eight of 13 patients were diagnosed within one year of corticosteroid treatment initiation. We had three patients with acute lymphoblastic leukaemia (ALL) in association with chemotherapy and high-dose corticosteroids. The patients who were on this therapy during diagnosis of ANFH continued to receive this therapy after vascularized iliac grafting (VIG) treatment. Despite treatment, ANFH increased and they underwent THA. In the patients with liver transplantation and renal failure, steroid treatment was cut preoperatively. The use of steroid had been stopped previously in the rest of the patients.

\section{DISCUSSION}

The most important finding of the present study was that improvement was lasting for a mean of three years after the vascular pedicled iliac bone grafting in three-fifth of the patients with early stages of femoral head avascular necrosis. These results are comparable to those reported in the literature. ${ }^{[15-18]}$

There is still no agreement on the best surgical method for ANFH yet. Conceptually, the best option is removal of the necrotic bone from the femoral head and replacement with a viable and structurally-sound bone, thus restoring vitality to the femoral head, preventing collapse of the articular surface, and delaying, THA, if prevention is unlikely. ${ }^{[10]}$ Several surgical approaches to preserve the hip for treatment of ANFH have been described including core decompression, various osteotomies, bone grafting (vascularized or nonvascularized). Bone grafting, regardless of the specific type, is an attractive treatment option. Most widely-used one is vascularized fibular grafts..$^{[9-12]}$ The fibula, with its corticocancellous bone stock, generous vascular pedicle (one artery and two accompanying veins) is applied for free vascularized
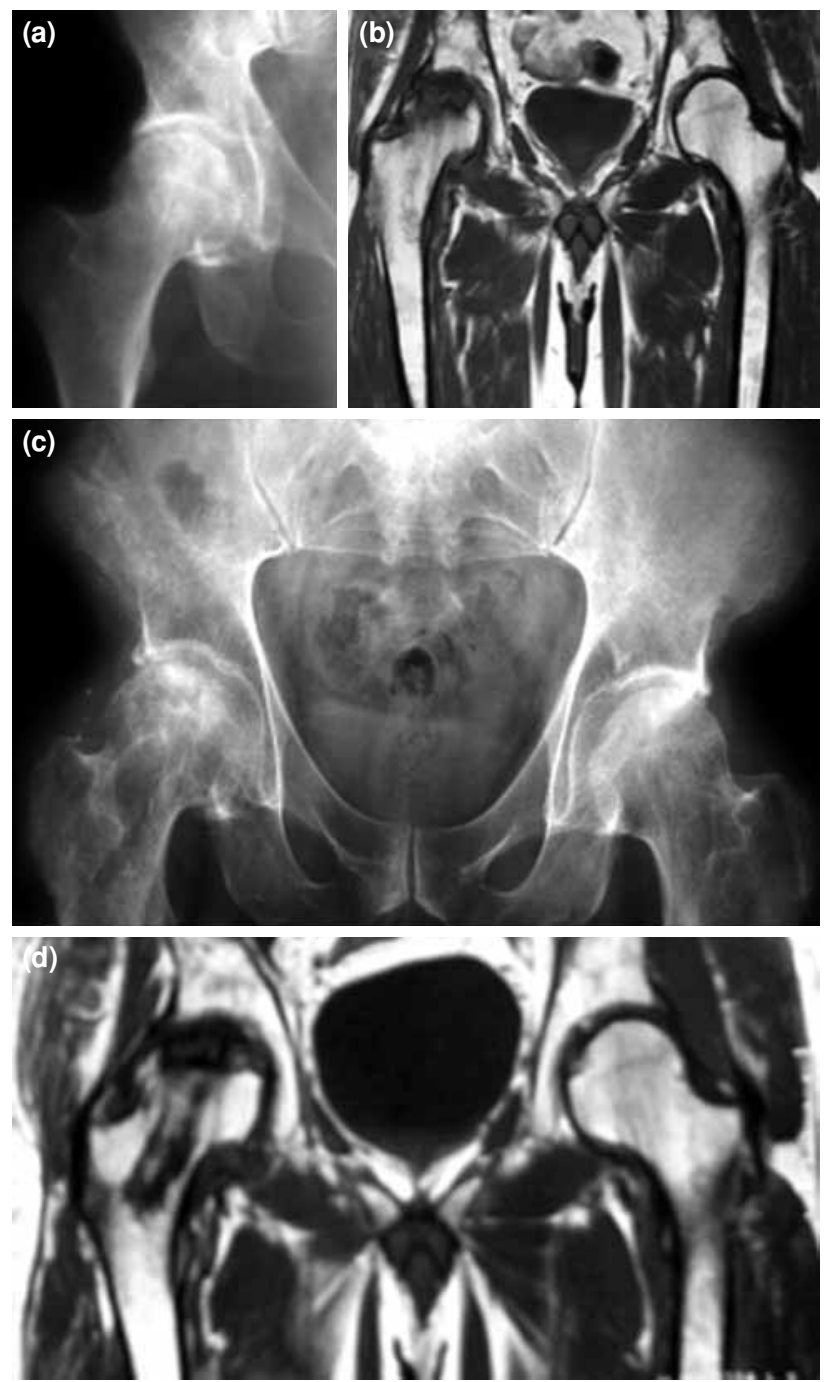

Figure 4. (a, b) Forty-seven-year-old man, preoperative X-ray and magnetic resonance imaging: ARCO stage III avascular necrosis. (c) Postoperative X-ray: Right side, three years after vascular pedicled graft applied. (d) Postoperative control magnetic resonance showing graft incorporation with no radiological evolution of the necrosis after three years. ARCO: Association internationale de recherche sur la circulation osseuse classification. 
bone graft transfer. The potential disadvantages of vascularized fibular grafting are prolonged surgery time, need of microvascular technique, prolonged operative scar, associated donor site morbidity, and heterotopic ossification. The insertion of a vascularized corticospongious iliac crest transplant perfused by the deep circumflex iliac artery in the femoral head produces a high-quality autogeneous bone transplant which is rich in osteoinductive factors and acts as a support helping to avoid the collapse of the femoral head. Additionally, removal of the necrotic or poorly vascularized bone has been replaced by a vascular structure with the supply of osteogenic precursor cells. The other advantages are no need for vessel anastomosis and low donor site morbidity. ${ }^{[14]}$

The success ratio reported in the literature ranges between $50 \%$ and $75 \%$. Iwata et al. ${ }^{[15]}$ reported that 17 of 23 stage II joints $(74 \%)$ treated with deep circumflex iliac artery pedicled iliac crest bone graft achieved satisfactory results at a mean of three years after surgery. In another study, Pavlovcic et al. ${ }^{[16]}$ reviewed 24 hips with avascular necrosis of the femoral head treated with vascularised iliac bone graft 12 years after the operation. Eight patients showed poor results, and six hips with fair results. The method was recommended for the treatment of the Ficat stage II and early stage III, when necrosis did not yet involve the femoral head completely. In a review of 226 hips applied pedicled iliac bone block, Zhao et al. ${ }^{[17]}$ showed that $6 \%$ required THA during 12.5 year-follow-up period. The procedure was successful in $96 \%$ at Ficat II, 90\% at Ficat III, 57\% at Ficat IV; Harris hip score increased from 46 to 84 . Matsusaki et al. ${ }^{[18]}$ used vascularized pedicle iliac bone graft combined with transtrochanteric anterior rotational osteotomy in patients with extensive necrosis in whom the necrotic area occupied more than two-thirds of the weight bearing zone of the femoral head. The mean Japanase Orthopaedic Association (JOA) score improved from 67.8 points preoperatively to 78.1 points by mean 50.7 months postoperatively. There was no disease progression to a more advanced stage in 12 of 17 hips (71\%) postoperatively. Zhao et al., ${ }^{[24]}$ reported a modified technique of tantalum rod implantation combined with vascularized iliac grafting for the treatment of ANFH. In their study, 52 patients (56 hips) ARCO stage II-IV treated with this technique were retrospectively reviewed at five years. Forty-three $(76.8 \%)$ of 56 hips remained stable on radiographs. Seven hips had to be converted to THA. Their overall succes rate of entire group was $87.5 \%$ according to ARCO staging system. ${ }^{[24]}$ However, contrast of the others, Chen et al., ${ }^{[19]}$ reported that the use of vascularized iliac bone grafting may not be as promising as originally suggested. They carried out a retrospective review of 33 hips treated with pedicled iliac bone block over the five years, resulting $76 \%$ required THA at mean of 74 months. Our results are comparable to those seen in the literature. In our patients radiologically preoperative 11 hips $(42 \%)$ had stage II and 15 hips (58\%) had stage III avascular necrosis according to the ARCO classification system. We had good-excellent results on the 18 hips (69\%) clinically and in 17 hips (65\%) necrosis remained at the same radiological stage after a mean follow-up of three years.

It is now well known that chronic and highdose steroid administration with or without immunosuppressive agents frequently are associated with the development of ANFH. ${ }^{[3]}$ Despite many theories which have been proposed, the precise mechanism of steroid induced osteonecrosis remains to be elucidated. Some authors have suggested that steroid use may induce ANFH exerting effects on the marrow blood supply, such as intraosseous hypertension, intravascular fat embolism and coagulation or compression of vessels by progressive accumulation of marrow fat stores or as a result of direct cytotoxic effects on cells. Thirteen of our patients had steroid use and three had ALL. These patients were continuing steroid use during diagnosis ANFH and after VIG treatment. Despite treatment $\mathrm{ANFH}$, disease progressed and they underwent THA.

There are some limitations to our study including the lack of intra- and interobserver reliability and control group, small sample size and short-term of follow-up.

\section{Conclusion}

While treatment of ANFH still poses a challenge to orthopedic surgeons, core decompression and vascularized iliac bone grafting are clinically effective and acceptable options in the treatment of the early stage of ANFH.

\section{Declaration of conflicting interests}

The authors declared no conflicts of interest with respect to the authorship and/or publication of this article.

\section{Funding}

The authors received no financial support for the research and/or authorship of this article. 


\section{REFERENCES}

1. Mont MA, Hungerford DS. Non-traumatic avascular necrosis of the femoral head. J Bone Joint Surg [Am] 1995;77:459-74.

2. Merle D'Aubigné R, Postel M, Mazabraud A, Massias P, Gueguen J, France P. Idiopathic necrosis of the femoral head in adults. J Bone Joint Surg [Br] 1965;47:612-33.

3. Wei SY, Esmail AN, Bunin N, Dormans JP. Avascular necrosis in children with acute lymphoblastic leukemia. J Pediatr Orthop 2000;20:331-5.

4. Lieberman JR, Berry DJ, Mont MA, Aaron RK, Callaghan JJ, Rajadhyaksha AD, et al. Osteonecrosis of the hip: management in the 21st century. Instr Course Lect 2003;52:337-55.

5. Flóris I, Bodzay T, Vendégh Z, Gloviczki B, Balázs P. Shortterm results of total hip replacement due to acetabular fractures. Eklem Hastalik Cerrahisi 2013;24:64-71.

6. Harris WH. Traumatic arthritis of the hip after dislocation and acetabular fractures: treatment by mold arthroplasty. An end-result study using a new method of result evaluation. J Bone Joint Surg [Am] 1969;51:737-55.

7. Wang SA, Zhang YC, Shih GL. Evaluation of new version of Mecbio hip resurfacing prosthesis. Eklem Hastalik Cerrahisi 2012;23:2-8.

8. Mont MA, Carbone JJ, Fairbank AC. Core decompression versus nonoperative management for osteonecrosis of the hip. Clin Orthop Relat Res 1996;324:169-78.

9. Aldridge JM 3rd, Urbaniak JR. Avascular necrosis of the femoral head: role of vascularized bone grafts. Orthop Clin North Am 2007;38:13-22.

10. Soucacos PN, Beris AE, Malizos K, Koropilias A, Zalavras $\mathrm{H}$, Dailiana Z. Treatment of avascular necrosis of the femoral head with vascularized fibular transplant. Clin Orthop Relat Res 2001;386:120-30.

11. Urbaniak JR, Coogan PG, Gunneson EB, Nunley JA. Treatment of osteonecrosis of the femoral head with free vascularized fibular grafting. A long-term follow-up study of one hundred and three hips. J Bone Joint Surg [Am] 1995;77:681-94.

12. Eisenschenk A, Lautenbach M, Schwetlick G, Weber U. Treatment of femoral head necrosis with vascularized iliac crest transplants. Clin Orthop Relat Res 2001;386:100-5.
13. Cano-Luis P, Ricón-Recarey FJ, Fuentes-Díaz A, LisónTorres A. Treatment of non-septic femoral head necrosis with a vascularized iliac crest graft. Rev Ortop Traumatol 2007;51:136-40.

14. Ishizaka M, Sofue M, Dohmae Y, Endo N, Takahashi HE. Vascularized iliac bone graft for avascular necrosis of the femoral head. Clin Orthop Relat Res 1997;337:140-8.

15. Iwata H, Torii S, Hasegawa $Y$, Itoh H, Mizuno M, Genda E, et al. Indications and results of vascularized pedicle iliac bone graft in avascular necrosis of the femoral head. Clin Orthop Relat Res 1993;295:281-8.

16. Pavlovcic V, Dolinar D, Arnez Z. Femoral head necrosis treated with vascularized iliac crest graft. Int Orthop 1999;23:150-3.

17. Zhao D, Xu D, Wang W, Cui X. Iliac graft vascularization for femoral head osteonecrosis. Clin Orthop Relat Res 2006;442:171-9.

18. Matsusaki H, Noguchi $M$, Kawakami T, Tani T. Use of vascularized pedicle iliac bone graft combined with transtrochanteric rotational osteotomy in the treatment of avascular necrosis of the femoral head. Arch Orthop Trauma Surg 2005;125:95-101.

19. Chen CC, Lin CL, Chen WC, Shih HN, Ueng SW, Lee MS. Vascularized iliac bone-grafting for osteonecrosis with segmental collapse of the femoral head. J Bone Joint Surg Am 2009;91:2390-4.

20. Leung PC, Chow YY. Reconstruction of proximal femoral defects with a vascular-pedicled graft. J Bone Joint Surg [Br] 1984;66:32-7.

21. Babhulkar S. Osteonecrosis of femoral head: Treatment by core decompression and vascular pedicle grafting. Indian J Orthop 2009;43:27-35.

22. Ficat RP. Aseptic necrosis of the femur head. Preliminary remarks concerning staging: stage O. Acta Orthop Belg 1981;47:239-41. [Abstract]

23. Gardeniers JW. A new international classification of osteonecrosis of the ARCO Committee on terminology and classification. J Jpn Orthop Assoc 1992;66:18-20.

24. Zhao D, Zhang Y, Wang W, Liu Y, Li Z, Wang B, et al. Tantalum rod implantation and vascularized iliac grafting for osteonecrosis of the femoral head. Orthopedics 2013;36:789-95. 